\title{
COMPARISON OF SOLVING ALGORITHMS FOR A MATHEMATICAL MODEL OF FILTRATION-DIFFUSION TRANSFER IN THE MEDIUM OF SPHERICAL MOISTURE-SATURATED MICROPOROUS PARTICLES
}

\author{
Mykhaylo Petryk; Dmytro Mykhalyk; Oksana Petryk
}

\author{
Ternopil Ivan Puluj National Technical University, Ternopil, Ukraine
}

\begin{abstract}
Summary. The article considers the use an analytical and numerical approaches for finding solutions of mathematical model of diffusion mass transfer in the medium of particles of microporous structure. The special software developed based on both approaches and these software were used for computer simulation of pressures in particles and interparticle space for spatial and temporal parameters of the filtration process, and the results were compared taking into account their accuracy and speed of production. Considered algorithms showed approximately the same accuracy in finding the pressure profiles. Analytical solution-based software has demonstrated the higher efficiency for calculating unit pressure values at given parameters, in turn, numerical techniques have been found to be convenient for building high-resolution profiles.

Key words: High-performance computing, nanoporous systems,;masstransfer, spherical moisturesaturated microporous particles, numerical methods.
\end{abstract}

Problem statement. The use of mathematical modeling aids for physical processes study has been an essential part of any technological process development for a long time. Mass transfer in nanoporous media and materials is one of the areas where mathematical modeling has been widely used. It enables us to design and develop the processes providing the high quality of finished products and materials which are used in different fields and industries from medicine to oil chemistry and aeronautics.

Analysis of the known results of the study. Computer approaches implementation for the study of processes in porous media involves both the construction of proper mathematical models and their parameters setting as well. The problems of mathematical models construction for the study of moisture saturated media filtration pressing taking into account physical parameters and special behavior of wet particles and their impact on general velocity and general process characteristics have been discussed in the previous papers [1-2]. The identification of mass transfer problems parameters in nanoporous media under specified distributions of the substance mass in solid and gaseous phases conditions has been studied in the papers [3-6]. Due to some difficulties in experimental distribution of the above-mentioned characteristics it's necessary to use the efficient computational algorithms to find the required parameters using the high-speed analytical methods taking into account the complex of the most important kinetics factors of transfer on macro- and micro levels. The implementation of modern computer aids to study the processes in the above-mentioned media involves not only some difficulties in proper mathematical models construction but their solutions efficient searching as well [7-10].

Paper purpose. The problems of creation and comparison of highly efficient tools of solutions constructions have been discussed in the paper. They must help to obtain on their basis the gradients of residual functional explicit expressions to identify the parameters of 
transfer in nanoporous media under specified total mass distribution conditions in solid and gaseous phases of the adsorbed substances.

Problem setting. The process of mass transfer in the porous medium layer of thickness $\mathrm{h}$ consisting of moisture-saturated microporous particles of radius $\mathrm{R}$ has been taken into consideration in the paper under discussion. The fluid outputs appearing in the internal particle space are considered to be directed into the interparticle space. Porous particles are considered as spheres of radius $\mathrm{R}$ separated from one another by micro pores. Thus, the whole layer of particles is considered as two-level system of pores: the system of micro- and nanopores having the high capacity degree of and low hydraulic penetration, and, vice versa, the system of macropores with low capacity degree and high hydraulic penetration.

The mathematical model of the filtration pressing under discussion can be described as the following system of differential equations [11]:

consolidation equation for a disperse medium layer:

$$
\frac{\partial P_{1}}{\partial t}=b_{1} \frac{\partial^{2} P_{1}}{\partial z^{2}}-\frac{b_{2}}{\theta R}\left(\frac{\partial P_{2}}{\partial r}\right)_{r=R},
$$

with initial and marginal conditions

$$
\left.P_{1}(t, z)\right|_{t=0}=0,\left.\quad P_{1}(t, z)\right|_{z=h}=P_{e}=1,\left.\quad \frac{\partial P_{1}(t, z)}{\partial z}\right|_{z=0}=0
$$

consolidation equation for a spherical particle

$$
\frac{\partial P_{2}}{\partial t}=b_{2}\left(\frac{\partial^{2} P_{2}}{\partial r^{2}}+\frac{2}{r} \frac{\partial P_{2}}{\partial r}\right),
$$

with conditions

$$
\left.P_{2}\right|_{t=0}=\left.0 \quad P_{2}\right|_{r=R}=P_{1}(t, z),\left.\quad \frac{\partial P_{2}}{\partial r}\right|_{r=0}=0 .
$$

The following symbols have been accepted: ${ }^{P_{1}}$ - distributed pressure in solid phase for interparticle space of the medium; $P_{2}$ distributed pressure in solid phase for intraparticle space of the medium (spherical particle); $b_{2}, b_{1}$ - consolidation coefficients micro pores of spherical particles and macro pores of interparticle space of the medium; $\theta$ - medium porosity coefficient; $\varepsilon$ - medium porosity; $\mathrm{h}$ - thickness of filtration medium layer; $\mathrm{R}$ - radius of the particle.

Algorithm of the problem analytical solution. The technique of the described problem solution finding has been described in [1,9] and it involves the use of Laplace integral transformations to the problem (1)-(4) and since the solutions being found in the transform domain, returning to the functions- originals with the help of Heaviside expansion theorem. In this case the coefficients $\beta_{\mathrm{k}, \mathrm{n}}$ which are the roots of the transcendental equation have been used. 


$$
\beta_{k n} \operatorname{ctg} \beta_{k n}-\theta \beta_{k n}^{2}=1-\left(n-\frac{1}{2}\right)^{2}\left(\pi \frac{R}{h}\right)^{2} \theta \frac{b_{1}}{b_{2}} .
$$

As a result, the following solutions have been obtained

$$
P_{1}(t, Z)=1+2 \pi \frac{R^{2}}{h^{2}} \frac{b_{1}}{b_{2}} \sum_{n=1}^{\infty} \sum_{k=1}^{\infty} \frac{(2 \mathrm{n}-1) \cos \left(\frac{2 \mathrm{n}-1}{2} \pi Z\right) \exp \left(-\frac{\beta_{k n}^{2}}{\mathrm{R}^{2}} b_{2} t\right)}{(-1)^{\mathrm{n}} \beta_{k n}^{2}\left[\frac{1}{\theta}\left(\frac{1}{\sin ^{2}\left(\beta_{k n}\right)}-\frac{\operatorname{ctg}\left(\beta_{k n}\right)}{\beta_{k n}}\right)+2\right]}
$$

$$
\begin{aligned}
& P_{2}(t, \rho, Z)= \\
& =2 \pi \sum_{n_{1}=1}^{\infty}\left[\begin{array}{l}
\frac{1-\exp \left(-\frac{n_{1}^{2} \pi^{2}}{R^{2}} b_{2} t\right)}{n_{1} \pi^{2}}+ \\
+2 \frac{R}{h} \frac{b_{1}}{b_{2}} \sum_{n=1}^{\infty} \sum_{k=1}^{\infty} \frac{\left.\left.\left.(2 n-1) \cos \left(\frac{2 n-1}{2} \pi Z\right) \cdot \frac{\exp \left(-\frac{\beta_{k n}^{2}-n_{1}^{2} \pi^{2}}{\mathrm{R}^{2}} b_{2} t\right)}{(-1)^{\mathrm{n}} \beta_{k n}^{2}\left[\frac{1}{\theta}\left(\frac{1}{\beta_{k n}^{2} / n_{l}-n_{1} \pi}\right)\right.}\right] \cdot \frac{\operatorname{ctg}\left(\beta_{k n}\right)}{\sin ^{2}\left(\beta_{k n}\right)}\right)+2\right]}{\left.(-1)^{n_{1}+1} \cdot \rho\right)}
\end{array}\right]
\end{aligned}
$$

Algorithm of the problem numerical solution building. The numerical solution of the model has been found using the Crank-Nicolson scheme [2, 7]. For this purpose, in areas $D_{1}$ and $D_{2}$ a uniform orthogonal grid has been introduced, and a layout chart has been shown on fig. 1 .

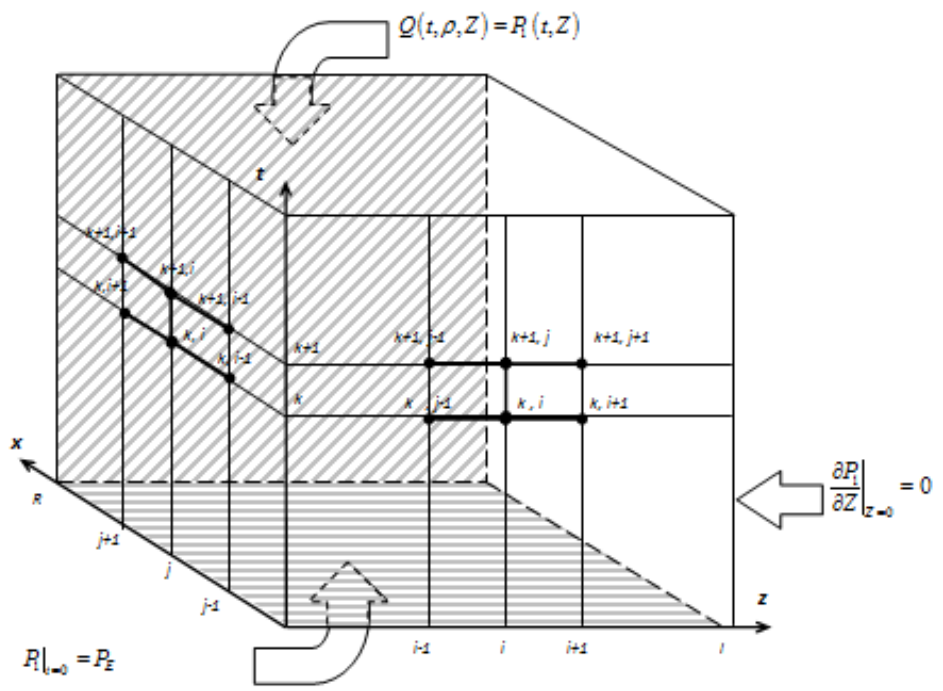

Figure 1. Layout for difference scheme 
As a transition to the chosen difference scheme, the initial problem (1)-(4) is being transformed into the system of the following difference equations:

$$
\begin{gathered}
P_{1_{i}}^{k+1}-P_{1_{i}}^{k}=\frac{b_{1}}{h^{2}} \frac{\Delta t}{2 \cdot \Delta z^{2}}\left[P_{1_{i+1}}^{k+1}-2 P_{1_{i}}^{k+1}+P_{1_{i-1}}^{k+1}+P_{1_{i+1}}^{k}-2 P_{1_{i}}^{k}+P_{1_{i-1}}^{k}\right]-\bar{Q}_{i}^{k}[], \\
Q_{i, j}^{k+1}-Q_{i, j}^{k}=\frac{b_{2}}{R^{2}} \frac{\Delta t}{2 \cdot \Delta \rho^{2}}\left[Q_{i, j+1}^{k+1}-2 Q_{i, j}^{k+1}+Q_{i, j-1}^{k+1}+Q_{i, j+1}^{k}-2 Q_{i, j}^{k}+Q_{i, j-1}^{k}\right] .
\end{gathered}
$$

The symbols used: $P_{1 i}^{k}$ - for the pressure value in i joint of k layer of interparticle space; $Q_{i j}^{k}$ - for the pressure value in in i joint of $\mathrm{k}$ layer of the particle space.

To find the pressure value in the intraparticle space for $(k+1)$-layer one should solve the system of equations (7) at $i=\overline{O, M}$, and to find the pressure value inside the particles - for each value i from the interval $[O, M]$ one must solve the system (8) at $j=\overline{O, L}$.

To implement the algorithm of numerical solution building of two-level mass transfer mathematical model for the process of filtration in moisture-saturated particles medium the following formulae have been used to calculate the values of pressure in interparticle space

$$
\begin{gathered}
P_{l i}^{k+1}=\alpha_{i}^{l} \cdot P_{l i+1}^{k+1}+\beta_{i}^{l} \alpha_{i}^{l}=-\frac{b^{l}}{a^{l} \cdot \alpha_{i-1}^{l}+d^{l}}, \quad \beta_{i}^{l}=\frac{f_{i}^{l}+a^{l} \beta_{i-1}^{l}}{a^{l} \cdot \alpha_{i-1}^{l}+d^{l}}, \\
P_{1 M-1}^{k+1}=\frac{f_{M-1}^{l}-\beta_{M-2}^{l}\left(a^{l}+b^{l}\right)}{\alpha_{M-2}^{l}\left(a^{l}+b^{l}\right)+d^{l}} \quad \alpha_{1}^{l}=-\frac{b^{l}}{d^{l}}, \beta_{l}^{l}=\frac{f_{l}^{l}}{d^{l}} .
\end{gathered}
$$

and to calculate the values of pressure for the space inside the particle - the formulae

$$
\begin{gathered}
Q_{i j}^{k+1}=\alpha_{i j}^{2} \cdot Q_{i j+1}^{k+1}+\beta_{i j}^{2}, \quad \alpha_{i j}^{2}=-\frac{b^{2}}{a^{2} \cdot \alpha_{i j-1}^{2}+d^{2}}, \quad \beta_{i j}^{2}=\frac{f_{j}^{2}+\beta_{j}^{2}}{a^{2} \cdot \alpha_{i j-1}^{2}+d^{2}} \\
Q_{i L-1}^{k+1}=\frac{f_{i L-1}^{2}-a^{2} \cdot \beta_{i M-2}^{2}-b^{2} \cdot P_{l i}^{k+1}}{a^{2} \cdot \alpha_{i M-2}^{2}+d^{2}}, \alpha_{i l}^{2}=-\frac{b^{2}+a^{2}}{d^{2}}, \quad \beta_{i l}^{2}=\frac{f_{i l}^{2}}{a^{2}} .
\end{gathered}
$$

While finding the value of intraparticle pressure $P_{2 i j}^{k}$ we have taken into consideration that $Q=\rho P_{2}$.

\section{Computer simulation and comparative analysis.}

The proper software based on the above-described algorithms of the mathematical model solutions of mass transfer for the moisture-saturated particles medium has been developed and used for the space-time pressure distribution modeling for macropores of the medium interparticle space $P_{1}(t, z)$ and micropores of particle space $P_{2}(t, x, z)$ [7,8]. 


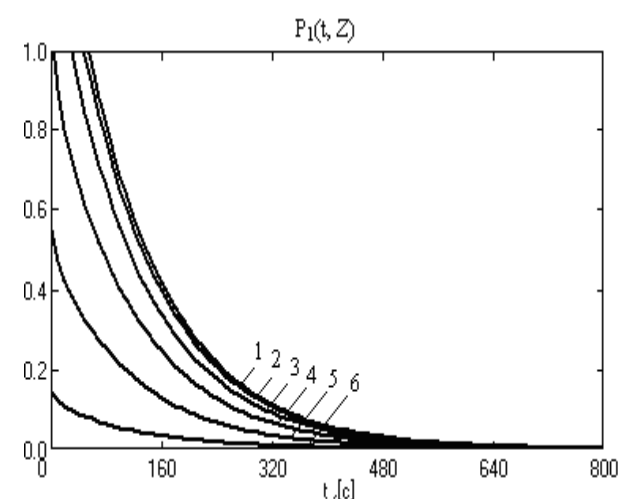

Figure 2. Profile of pressure change in macropores of interparticle space depending on time $\mathrm{t},[\mathrm{c}]$

1) $\mathrm{Z}=0.1$; 2) $\mathrm{Z}=0.2$; 3) $\mathrm{Z}=0.3$; 4) $\mathrm{Z}=0.4$; 5) $\mathrm{Z}=0.6$; 6) $\mathrm{Z}=0.9$

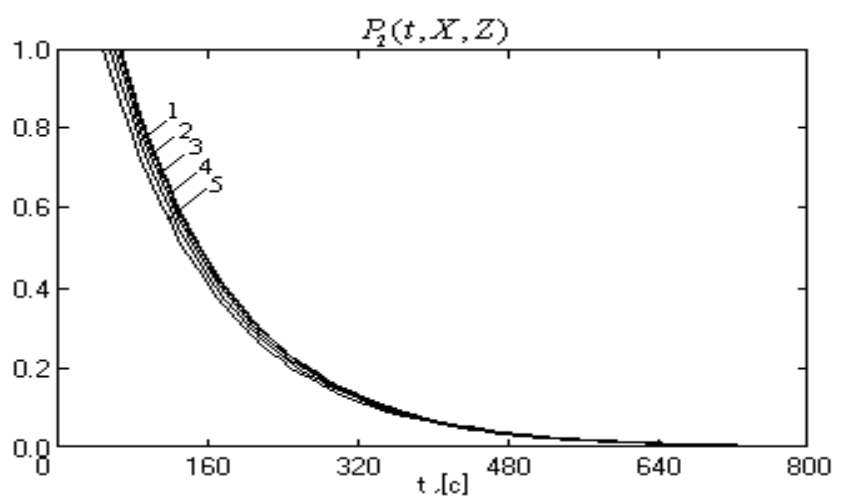

Figure 3. Profile of pressure change in particle micropores depending on time $\mathrm{t},[\mathrm{c}]$ 1) $\mathrm{X}=0.05$; 2) $\mathrm{X}=0.2$; 3) $\mathrm{X}=0.5$; 4) $X=0.8$; 5) $X=1$

Figures 2 and 3 show the pressure dependencies on the time t interparticle space of the medium $P_{1}(t, z)$ and pressure in micropores of spherical particles $P_{2}(t, \rho, Z)$. Values $\mathrm{Z}=0$ corresponds to the position of the particles on the level of inner surface of the press, $\mathrm{Z}=0.5$ - inside the medium and at $\mathrm{Z}=0$ the particles are next to the filtration membrane.

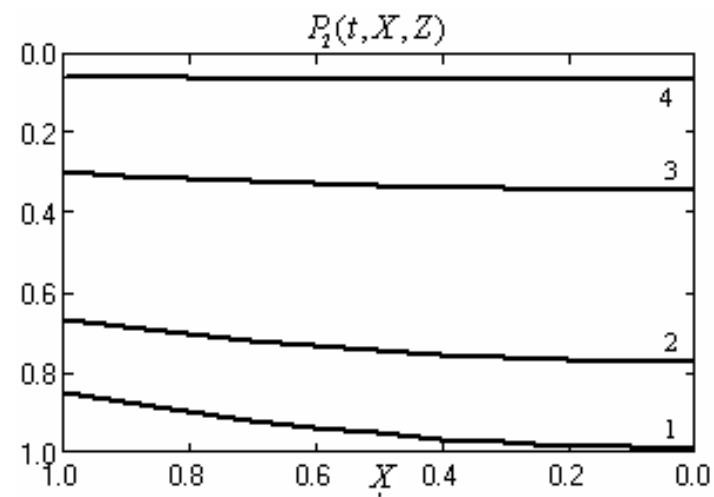

Figure 4. Profile of pressure change in particle micropores $(\mathrm{Z}=1)$

1) $\mathrm{t}=70 \mathrm{c} ; 2$ ) $\mathrm{t}=100 \mathrm{c} ; 3) \mathrm{t}=200 \mathrm{c} ; 4) \mathrm{t}=400 \mathrm{c}$

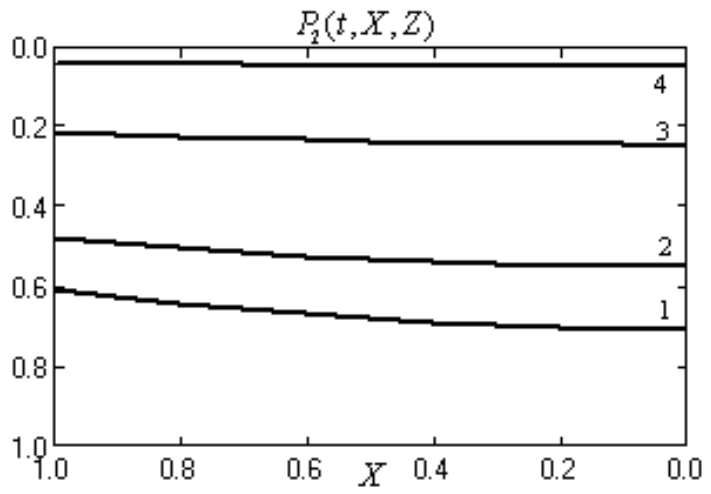

Figure 5. Profile of pressure change in particle micropores $(\mathrm{Z}=0.5)$

1) $\mathrm{t}=70 \mathrm{c}$; 2) $\mathrm{t}=100 \mathrm{c} ; 3) \mathrm{t}=200 \mathrm{c}$; 4) $\mathrm{t}=400 \mathrm{c}$

Figures 4 and 5 show the simulated values of pressure in micropores of spherical particles $P_{2}(t, X, Z)$ on the radius of particle $\mathrm{X}$ for the particles which are close to the filtration press $(Z=1)$ and inside the medium layer $(Z=0.5)$ for different moments of time $t$ during the process of filtration pressing.

Having made the comparative analysis of the mathematical model solutions (1) (4) in computer modeling of kinetic characteristics profiles, we must admit that the both algorithms have shown practically the same accuracy of the obtained profiles values. As for the efficiency, the algorithm with the use of analytical solution is quicker for the single pressure values obtaining under specified parameters conditions $\mathrm{Z}, \mathrm{X}$ and time, and requires considerably less amount of computation to be involved. As for the numerical algorithm, it is useful in case of profiles construction of pressure values with highly intensive values in the profile as the calculations are made for the whole grid at once and after that none extra 
resources are not required. We should also mention that the numerical algorithm requires more operation memory in comparing to the analytical one.

Conclusions. The use of two schemes of solutions construction for the model of diffuse mass transfer in the medium of microporous particles represented by the system of differential equations with marginal conditions has been considered in the paper under discussion. This investigation is extremely important for both the development of highly efficient aids of pressure profiles computer modeling and for the identification of transfer parameters in nanoporous media on the basis of gradient methods under specified mass total distribution in solid and gaseous phases of adsorbed substances as well.

\section{References}

1. Petryk M., Vorobiev E. Liquid Flowing from Porous particles During the Pressing of Biological Materials. Computer \& Chem. Eng. Elsevier Irland. Issue 31. 2007. P. 1336-1345. DOI: https://doi.org/10.1016/j.compchemeng.2006.12.011

2. Sergienko I., Petryk M., Khimich A., Mykhalyk D., Leclerc S., Fraissard J. Matematychne modeliuvannia masoperenosu v seredovyshchakh chastynok nanoporystoi struktury. Natsionalna akademiia nauk Ukrainy, Kyiv., 2014, 196 p. [In Ukrainian].

3. Deineka V. Petryk M, Canet D., Fraissard J. Matematychne modeliuvannia ta identyfikatsiia parametriv masoperenosu v neodnoridnykh i nanoporystykh seredovyshchakh, National Academy of Sciences of Ukraine. Kyiv, 2014, 182 p. [In Ukrainian].

4. Petryk M., Mykhalyk D., Petryk O., Kordiak I. Identyfikatsiia koefitsiientiv konsolidatsii protsesu vidtysku "tverde tilo - ridyna" dlia konsolidatsii seredovyshch chastynok mikroporystoi struktury, Visnyk of Kherson National Technical University. No. 3 (62). 2017. P. 85-90. [In Ukrainian].

5. Petryk M. High Velocity Identification Methods of the Model Parameters of Filtration-Consolidation of Compressible Media of Moisture-Saturated Micro-Porous Particles. Journal of Automation and Information Sciences. Vol. 48. Issue 1. 2016. P. 69-83. DOI: https://doi.org/10.1615/JAutomatInfScien.v48.i1.80

6. Petryk M. Retrospective Identification Problem in Integrated Form from Systems of Filtration-Consilidation of Compressible Media of Liquid Contained Microporous Particles. Journal of Automation and Information Sciences. Vol. 48. Issue 8. 2016. P. 1-14. DOI: https://doi.org/10.1615/JAutomatInfScien.v48.i8.10

7. Petryk M., Vorobiev E. Numerical and Analytical Modeling of Solid-Liquid Expression from Soft Plant Materials. AIChE Journal. Wiley. Volume 59. Issue 12. 2013. P. 4762-4771. DOI: https://doi.org/10.1002/aic.14213

8. Petryk M., Khimitch A., Petryk M. M., Fraissard J. Experimental and computer simulation studies of dehydration on microporous adsorbent of natural gas used as motor fuel. Fuel. Vol. 239. 2019. P. 13241330. DOI: https://doi.org/10.1016/j.fuel.2018.10.134

9. Petryk M., Khimich O., Mykhalyk D., Boyko I., Kovbashyn V. (2019) High-performance computing technologies of modeling and identification of adsorption in nanoporous systems with feedbacks for gas purification. Scientific Journal of TNTU (Tern.). Vol. 95. No. 3. P. 139-145. DOI: https://doi.org/10.33108/visnyk_tntu2019.03.139

10. Petryk M., Boyko I., Mykhalyk D., Petryk M., Lutsyk N., Kovbashyn V. (2017) Mathematical modeling of processes of nonisothermal adsorption, desorption and heat transfer of hydrocarbons in nanoporous catalysts based on zeolite ZSM-5 of exhaust gas neutralization systems. Scientific Journal of TNTU (Tern.). Vol. 88. No. 4. P. 145-152. DOI: https://doi.org/10.33108/visnyk_tntu2017.04.145

11. Webster A. Differencial'nye uravneniya v chastnyh proizvodnyh matematicheskoj fiziki 2nd edition. Dover Publications, 2016, 400 p. [In Russian].

\section{Список використаної літератури}

1. Petryk M. Liquid Flowing from Porous particles During the Pressing of Biological Materials. Computer \& Chem. Eng. Elsevier Irland. Issue 31. 2007. P. 1336-1345. DOI: https://doi.org/10.1016/j.compchemeng.2006.12.011

2. Сергієнко I. В., Петрик М. Р., Хіміч О. М., Кане Д., Михалик Д. М., Леклерк Д., Фрессард Ж. Математичне моделювання масопереносу в середовищах частинок нанопористої структури. Київ: Національна академія наук України, 2014. 196 с.

3. Дейнека В. С., Петрик М. Р., Кане Д. та Фрессар Ж. Математичне моделювання та ідентифікація параметрів масопереносу в неоднорідних і нанопористих середовищах. К.: Національна академія наук України. Інститут кібернетики імені В. М. Глушкова, 2014. 182 с.

4. Петрик М., Михалик Д., Петрик О., Корядк І., Петрик М. Ідентифікація коефіцієнтів консолідації процесу відтиску «тверде тіло - рідина» для консолідації середовищ частинок мікропористої структури. Вісник Херсонського національного технічного університету. № 3 (62). 2017. Р. 85-90. 
5. Petryk M. High Velocity Identification Methods of the Model Parameters of Filtration-Consolidation of Compressible Media of Moisture-Saturated Micro-Porous Particles. Journal of Automation and Information Sciences. Vol. 48. Issue 1. 2016. P. 69-83. DOI: https://doi.org/10.1615/JAutomatInfScien.v48.i1.80

6. Petryk M. Retrospective Identification Problemin Integrated Form from Systems of Filtration-Consilidation of Compressible Media of Liquid Contained Microporous Particles. Journal of Automation and Information Sciences. Vol. 48. Issue 8. 2016. P. 1-14. DOI: https://doi.org/10.1615/JAutomatInfScien.v48.i8.10

7. Petryk M., Vorobiev E. Numerical and Analytical Modeling of Solid-Liquid Expression from Soft Plant Materials. AIChE Journal. Wiley. Volume 59. Issue 12. 2013. P. 4762-4771. DOI: https://doi.org/10.1002/aic.14213

8. Petryk M., Khimitch A., Petryk M. M., Fraissard J. Experimental and computer simulation studies of dehydration on microporous adsorbent of natural gas used as motor fuel. Fuel. Vol. 239. 2019. P. 13241330. DOI: https://doi.org/10.1016/j.fuel.2018.10.134

9. Petryk M., Khimich O., Mykhalyk D., Boyko I., Kovbashyn V. High-performance computing technologies of modeling and identification of adsorption in nanoporous systems with feedbacks for gas purification. Scientific Journal of TNTU. 2019. Vol. 95. No. 3. P. 139-145. DOI: https://doi.org/10.33108/visnyk_tntu2019.03.139

10. Petryk M., Boyko I., Mykhalyk D., Petryk M., Lutsyk N., Kovbashyn V. Mathematical modeling of processes of nonisothermal adsorption, desorption and heat transfer of hydrocarbons in nanoporous catalysts based on zeolite ZSM-5 of exhaust gas neutralization systems. Scientific Journal of TNTU. 2017. Vol. 88. No. 4. P. 145-152. DOI: https://doi.org/10.33108/visnyk_tntu2017.04.145

11. Вебстер А. Дифференциальные уравнения в частных производных математической физики. Довель паблішінг. 2006. 400 с.

\title{
УДК 519.6
}

\section{ПОРІВНЯННЯ АЛГОРИТМІВ ПОШУКУ РОЗВ'ЯЗКІВ ДЛЯ МАТЕМАТИЧНОЇ МОДЕЛІ ФІЛЬТРАЦІЙНО-ДИФУЗІЙНОГО ПЕРЕНОСУ В СЕРЕДОВИЩІ СФЕРИЧНИХ НАСИЧЕНИХ ВОЛОГОЮ МІКРОПОРИСТИХ ЧАСТИНОК}

\author{
Михайло Петрик; Дмитро Михалик; Оксана Петрик
}

\section{Тернопільський начіональний технічний університет імені Івана Пулюя, Тернопіль, Україна}

\begin{abstract}
Резюме. Розглянуто використання різних підходів до побудови розв'язків математичної моделі дифузійного масопереносу в середовищі частинок мікропористої структури, щчо розглядається як дворівнева система пор: система мікро- $і$ нанопор, яка володіє високим ступенем місткості та низькою гідравлічною проникністю, та система макропор, навпаки з низьким рівнем місткості та високою гідравлічною проникністю. Методика побудови аналітичного розв'язку полягає в застосуванні до рівнянь задачі інтегрального перетворення Лапласа та повернення до функиій-оригіналів з допомогою теореми про розвинення Гевісайда. Методика побудови числового розв'язку базується на застосуванні схеми Кранка-Ніколсон до рівнянь задачі та застосування методу прогонки для відшукування коефіцієнтів розв'язків. Із використанням обидвох розв'язків проведено комп 'ютерне моделювання тисків у частинках та міжчастинковому просторі для просторових та часових параметрів процесу фільтраційного відтиску. Здійснено порівняння результатів з урахуванням їх точності та швидкості отримання. Обидва розглянуті алгоритми відшукування розв 'язків показали практично ідентичну точність щодо отриманих значень профілів тиску. 3 точки зору ефективності, то алгоритм із використанням аналітичного розв'язку очікувано виявився швидшим для випадків обчислення одинарного значення тисків при конкретно заданих параметрах та потребував меншу кількість обчислювальних ресурсів для використання. В свою чергу, чисельний алгоритм продемонстрував гарні показники при побудові профілів значень тисків 3 високою роздільною здатністю профілю, так як обчислення проводяться для усієї сітки розбиття одразу і після цьього жодних додаткових ресурсів не вимагають. Чисельний алгоритм також потребував значно більше оперативної пам'яті для роботи.
\end{abstract}

Ключові слова: високоефективні обчислення, нанопористі системи, масоперенос, сферичні мікропористі частинки, чисельні методи. 